Revue d'histoire de l'Amérique française

6. REVUE D.HISTOIRE DE L'AMÉRIQUE FRANÇAISE

\title{
Revues qui s'ajoutent à nos collections
}

Volume 22, numéro 4, mars 1969

URI : https://id.erudit.org/iderudit/302845ar

DOI : https://doi.org/10.7202/302845ar

Aller au sommaire du numéro

Éditeur(s)

Institut d'histoire de l'Amérique française

ISSN

0035-2357 (imprimé)

1492-1383 (numérique)

Découvrir la revue

Citer ce document

(1969). Revues qui s’ajoutent à nos collections. Revue d'histoire de l'Amérique

française, 22(4), 661-661. https://doi.org/10.7202/302845ar d'utilisation que vous pouvez consulter en ligne.

https://apropos.erudit.org/fr/usagers/politique-dutilisation/ 


\section{REVUES qui s'ajoutent à nos collections :}

Forces - revue d'information publiée trois fois l'an par les Relations publiques de l'Hydro-Québec, 75 ouest, Dorchester, Montréal. Nos 1-5.

Acta criminologica - Etudes sur la conduite antisociale - revue publiée par les Presses de l'Université de Montréal, vol. II, janvier 1969: "Vaudou en Haïti" - "Woman and Crime" - "Délinquance au Japon".

L'Actualité économique - index des matières 1925-1950 - revue trimestrielle publiée par l'Ecole des Hautes Etudes commerciales, Montréal.

Bulletin de la Bibiothèque Nationale - Ministère des Affaires culturelles du Québec, vol. 2, nos 2, 3, 4 .

Assurances - revue trimestrielle consacrée à l'étude théorique et pratique de l'assurance au Canada. Montréal, 410 rue Saint-Nicolas. 36e année, janvier 1969 , no 4.

Horizons - revue trimestrielle marxiste. 1967-1968.

Repertorio Historico de la Academia Antioquena de Historia - Republica de Colombia, nos 199, 200, 201 (1967-1968).

Humanisme - Centre de documentation du Grand Orient de France, nov.déc. 1968.

Socialisme - Revue du socialisme international et québecois. Montréal, no $16,1969$.

La Revue du Bas-Poitou et des provinces de l'Ouest, fondée en 1888 par René Vallette. Revue régionaliste, organe d'expression de la Société des Amis du Bas-Poitou.

NDLR - L'Introduction au compte rendu de Canada-Unity in Diversity de Cornell, Hamelin, Ouellet et Trudel, parue dans notre no de décembre 1968, pages 450-451, était l'œuvre des trois critiques. Il aurait alors fallu lire à la signature: Jean Blain, René Durocher et Jean-Pierre Wallot. 